\title{
EXCELLENT ACADEMIC ACHIEVEMENT: DO INTELLECTUAL HUMILITY AND EMOTIONAL INTELLIGENCE MATTER?
}

\author{
Aurelius Ratu*, Ni Gusti Made Rai, Eka Dian Savitri \\ Sepuluh Nopember Institute of Technology, Indonesia \\ *e-mail: aurelius.ratu@its.ac.id
}

\begin{abstract}
Since emotional intelligence receives much attention in the context of academic success and intellectual humility is frequently studied in the context of career path, research concerning the relationship between emotional intelligence and intellectual humility on academic achievement is a necessity. This study aims to investigate that relationship while contributing to higher education on the insight to an employable graduate. The quantitative approach was implemented as the research framework by applying independent $\mathrm{t}$-test and multiple regression in the first and second phases respectively. We found that the total score of intellectual humility and emotional intelligence for students (male and female) in the first year have a significant effect, while only the total score of intellectual humility among male in the second year has a significant effect on GPA $(n=531)$. Acknowledging academic achievement is an important variable in student's academic process and intellectual humility to continuously plan, adapt, adjust, and evaluate their set of competencies, while simultaneously their engagement in a non-academic activity should be fostered. Besides, we suggest a mentor programme on both career and academic dimensions to make them enjoy and comfortable during their educational process. An understanding of IH during the educational process is impossible without serious attention to emotion, including the religious dimension.
\end{abstract}

\section{Keywords: achievement, education, emotional, intellectual, student.}

\section{PRESTASI AKADEMIK YANG EKSELEN: APAKAH KERENDAHHATIAN INTELEKTUAL DAN KECERDASAN EMOSI BERARTI?}

\begin{abstract}
Abstrak: Kecerdasan emosional mendapat banyak perhatian dalam konteks prestasi akademis dan kerendahhatian intelektual sering dipelajari dalam konteks karir, penelitian tentang hubungan antara kecerdasan emosional dan kerendah hatian intelektual dengan prestasi akademik menjadi suatu keharusan. Studi ini bertujuan untuk menyelidiki hubungan tersebut sambil memberikan kontribusi pada pendidikan tinggi tentang pemahaman akan kemampuan kerja lulusan. Pendekatan kuantitatif digunakan sebagai kerangka penelitian dengan menerapkan uji- $t$ independen dan regresi berganda masing-masing pada tahap pertama dan kedua. Penelitian menemukan bahwa skor total kerendahhatian intelektual dan kecerdasan emosional mahasiswa (laki-laki dan perempuan) tahun pertama berpengaruh signifikan, sedangkan skor total kerendahhatian pada laki-laki tahun kedua berpengaruh signifikan terhadap IPK $(n=531)$. Dengan mengakui prestasi akademik merupakan variabel penting dalam proses pembelajaran akademik, kerendahhatian intelektual para mahasiswa untuk terus merencanakan, beradaptasi, menyesuaikan, dan mengevaluasi sekumpulan kompetensi serta keterlibatan mereka dalam kegiatan nonakademik harus terus dipupuk. Selain itu, disarankan program mentor pada dimensi karir dan akademik agar para mahasiswa menikmati dan nyaman selama proses pendidikan. Pemahaman tentang kerendahhatian selama proses pendidikan tidak mungkin dilakukan tanpa perhatian serius atas kecerdasan emosi termasuk dimensi religius.
\end{abstract}

Kata Kunci: prestasi, pendidikan, emosi, intelektual, mahasiswa.

\section{INTRODUCTION}

The learning process in the education system aims to produce qualified graduates emotionally and intellectually. An understanding of 'qualified graduates' today, in the context of Indonesia, tends to be reduced to only the perspective of grades. This tendency has become a token in developing countries (Ahmed, Asim, \& Pellitteri, 2019; Jan, Anwar, \& Warraich, 2018). Although several studies reported there 
is an influence of emotions on character and competence as one of the preparations for entering the work environment, emotions are nonetheless regarded only as intrinsic factors, i.e., influential factors as predictors for academic achievement. An understanding of qualified graduates already posits a positive correlation that students with high emotions have a good or high grade. Several studies have demonstrated the evidence and have been conducted during the past ten years. Most of these studies reported a positive correlation between emotions and academic achievement of students (Ahmed et al., 2019), emotions and motivation as well as attitude of learning (Baba, Makhdoomi, \& Siddiqi, 2019; Chinyere \& Afeez, 2019), emotions and career (Yeoh, 2019). Such a positive correlation, however, did not distinguish the level of difficulty and influence of the emotional intelligence over a certain period (different years) in the academic levels (Barchard, 2003). Therefore, these results have overlooked academic areas in which emotional intelligence might be necessary. Students might have a high level of emotion but using it to bring up new ideas and creativity in the context of education (for example, creating innovations in the form of online applications) so far has not been demonstrated unless only as a comparative study between Malaysian and Indonesian students (Ngah, Wahyukaton, Salleh, \& Sarmidy, 2016). Such difficulties can possibly lead to perplexity in the interpretation of a statistical result from the emotional intelligence model, so to speak if only perceiving emotions and managing own emotions are significant while others are not.

While dealing with such difficulties, we propose intellectual humility as a comparative model for a better understanding of the emotional construct. On one side, emotions can help guide decision-making, organize people toward goals, needs, concerns, and motivate people toward specific adaptive actions designed. On the other side, emotion informs cognition to conduct reasoned action (Church \& Samuelson, 2017). The ability to learn new things and accept differences that may not be following the principles, such as a religious principle or doxastic view, should be taken into account as a comparison towards EI for getting a better understanding and interpretation. Several studies have suggested that intellectual humility influences a student's academic success, self- perceived competence, career adaptability (Baehr, 2017; Krumrei-Mancuso, Haggard, LaBouff, \& Rowatt, 2020).

A student's ability to accept and be opened to ideas that might conflict with one's principles/knowledge is one thing that needs to be considered as correlating with emotions. The task performance, level of difficulty, expectations, and future goals of life involves both emotional intelligence and intellectual humility in an academic process. In the context of higher education, some contribution of both constructs can be similarly seen from Jenaabadi (2014) who showed that there is no relationship between emotional intelligence and self-esteem with academic achievement except for the selfesteem degree between female and male students and Majeski, Stover, Valais, \& Ronch (2017) who suggested the importance of emotional intelligence while equivocally admitting cooperation and problem-solving as a kind of intellectual ability. Also, the so-called 'soft-skill' term which illustrates intellectual virtues such as employability, curiosity, open-mindedness, intellectual autonomy, and intellectual humility as well as bridges a smooth transition from university to workplace might be a more realistic prospect of educational goals (Baehr, 2016).

In 1990, Salovey and Mayer proposed the existence of new intelligence, called 'emotional intelligence,' as the cognitive ability (Mayer, Caruso, \& Salovey, 2016; Mayer, Salovey, \& Caruso, 2008): the ability to understand and reason about emotions. The rationale is that the use of emotions and the use of information are different for each person. Someone can be better motivated at work because he/she can process the emotions into something useful (for example, anger to satisfaction). TIME (1995) magazine claimed that "Emotional Intelligence may be the best predictor of success in life, redefining what it means to be smart" (Barchard, 2003). In the last ten years, there are two models used as a research tool in the education process, namely the ability model (Chinyere \& Afeez, 2019) and trait/mixed models (Ahmed et al., 2019). Until this day, no researchers have dared to declare that one model has more advantages than another model.

The original model of EI developed and later updated by Mayer et al. (2016) focuses on problem-solving. There are four-branch 
ability models: perceiving emotions, facilitating thought using emotions, understanding emotions, and managing emotions. Meanwhile, the mixed model of EI claimed that EI is a combination of cognitive ability and personality ability. This model proposed that emotional intelligence consists of an appraisal of emotion in the self and others, expression of emotion, regulation of emotion in the self and others, and utilization of emotion in solving problems. Like the ability model, the mixed model proposed four branches: perception of emotion, managing their own emotions, managing others' emotions, and utilization of emotion (Bhullar, 2009). In this current study, we adopted a mixed model approach.

Meanwhile, the topic of intellectual humility has a root in the philosophical discourse, which then continues to theology, and finally, it has been elaborated by psychology. Some studies classified humility as a virtue (Kidd, 2011), some classified it as a moral aspect by discussing it in inter-disciplinary of theology and psychology (Dormandy, 2018). Because of the broad scope of the existing discussion, we confined our research to the formulas given by (Krumrei-Mancuso, 2017; Krumrei-Mancuso \& Rouse, 2016) as having an intellectual dimension for being able in openness to revising one's viewpoints, lack of overconfidence about one's knowledge, respect for the viewpoints of others, and lack of threat in the face of intellectual disagreements. The four constructs are referred to Comprehensive Intellectual Humility as an attempt to be as comprehensive as possible in synthesizing general intellectual humility (Leary et al., 2017) and specific intellectual humility (Hoyle, Davisson, Diebels, \& Leary, 2016). Although it was said that no instrument could be "comprehensive" in assessing intellectual humility (Church \& Samuelson, 2017), this concept or construct can give and bridge philosophy and psychology. This concept has also been discussed in many areas of education to understand how Intellectual Humility affects learning motivation (Schei, Fuks, \& Boudreau, 2019; Wrench, Punyanunt-Carter, \& Garcia, 2020), acceptance of adaptive behavior for differences (Hopkin, Hoyle, \& Toner, 2018; Watson, 2018), and preparation for the world of work (Schei et al., 2019).

Understanding IH and EI in a combination of interdisciplinary studies is a relatively new effort. Several studies have attempted to examine this relationship such as the admission of wrongness (Fetterman, Curtis, Carre, \& Sassenberg, 2019), win by cheating: achievement goal approach (Van Yperen, Hamstra, \& Van Der Klauw, 2011), religious teachings as specific views with humility (Hoyle et al., 2016), spiritual awfulness linked to happiness and positive emotions (Preston \& Shin, 2017), and emotions and faith development (Wrench et al., 2020). Such studies illustrated the increasing attention paid to the relationship between emotions and humility. So, this paper aims to investigate the relationship between emotional intelligence and intellectual humility on academic achievement as well as contribute to an understanding of the interplay of both variables in the process of higher education. In addition, this study hopefully can enrich Indonesian works of literature and stimulate decision makers in higher education that in fact more than fifty percent of graduates had a study-mismatched job (Mardiana, 2017).

\section{METHODS \\ Measures and Participants}

For our purpose, we adapted and translated a tested questionaire Emotional Intelligence (EI) and Intellectual Humility (IH) into Indonesian. Emotional intelligence measure consists of 33 items (Schutte, Malouff, Hall, Haggerty, Cooper, Golden, \& Dornheim, 1998) and Intellectual Humility measure consists of 22 items (KrumreiMancuso \& Rouse, 2016) (see appendix). All statements were assessed by a 5-point scale upon which students gave their approval from strongly disagree (1) to strongly agree (5). Emotional intelligence and intellectual humility statements were acceptable at .88 and .75 Cronbach's alpha. In confirming the validity, we also conduct factor analysis with Kaiser-Meyer-Olkin model as displayed in Table 1. Because KMO's value for both IH and EI are greater than .05, it means that all items are valid.

Five hundred and thirty-one students were asked to fill in a self-report questionnaire. It was conducted during the regular period of the learning process. The data is shown in Table 2. 
Table 1. Validity Scale based on Kaiser-Meyer-Olkin

\begin{tabular}{llll}
\hline & IH & EI \\
\hline Kaiser-Meyer-Olkin Measure of Sampling Adequacy. & .80 & .88 \\
Bartlett's Test of Sphericity & Approx. Chi-Square & 3328.62 & 4925.19 \\
& $d f$ & 231 & 528 \\
& Sig. & .00 & .00 \\
\hline
\end{tabular}

Note: $\mathrm{KMO}>=.50$ means valid

Table 2. Contingency Table Showing Socio-Demographic $(N=531)^{*}$

\begin{tabular}{|c|c|c|c|c|c|}
\hline & & \multicolumn{2}{|c|}{ First Year } & \multicolumn{2}{|c|}{ Second Year } \\
\hline & & Male & Female & Male & Female \\
\hline \multirow[t]{2}{*}{ Participating in social/religious activities } & Yes & 30 & 82 & 27 & 25 \\
\hline & No & 112 & 167 & 40 & 48 \\
\hline \multirow[t]{4}{*}{ Age } & $15-17$ & 9 & 5 & 3 & 5 \\
\hline & $18-20$ & 131 & 61 & 60 & 61 \\
\hline & $21-23$ & 1 & 7 & 4 & 7 \\
\hline & $>23$ & 1 & 0 & 0 & 0 \\
\hline \multirow[t]{5}{*}{ GPA } & $<2.00$ & 4 & 8 & 0 & 2 \\
\hline & $2.01-2.5$ & 3 & 2 & 3 & 6 \\
\hline & $2.51-3.00$ & 15 & 11 & 9 & 15 \\
\hline & $3.01-3.50$ & 64 & 111 & 32 & 34 \\
\hline & $>3.51$ & 56 & 117 & 23 & 16 \\
\hline TOTAL & & 142 & 249 & 67 & 73 \\
\hline
\end{tabular}

Note: *total number of the students based on cases with valid responses

\section{Data Analysis}

The questionnaire by the end of the academic year was distributed. Specifically, the students in the first year who have not yet received a GPA were asked to fill in the GPA according to expectations and based on their ability to complete the assignments given. With the selection of situations for the spread of the questionnaire, the effect of both EI and IH based on different years, gender, and religious activities were analyzed to see the significant differences in each of those variables. Therefore, the first hypothesis was that there are significant differences in the level of academic years, gender and religious activities relating to EI and $\mathrm{IH}$. For this first hypothesis, an independent $t$-test model was conducted. From the results obtained, then the analysis with the regression method for estimating the significance of explanatory variables was held. At this stage, the hypothesis was that there exists a significant relationship between emotional intelligence and intellectual humility on academic achievement.

\section{FINDINGS AND DISCUSSION Findings}

The mean, standard deviation, min-max score, and GPA mean can be seen in Table 3. After the scale measurement was conducted, we proceeded with independent $t$-test analysis, as shown in Table 4.

Table 3. The Descriptive Statistic for EI, IH, and GPA

\begin{tabular}{lrrcc}
\hline & $\boldsymbol{M}$ & $\boldsymbol{S D}$ & Min & Max \\
\hline EI (33 items) & 128.72 & 12.62 & 94 & 164 \\
IH (22 items) & 78.22 & 7.91 & 58 & 102 \\
GPA mean for student's first year & 3.31 & .88 & & \\
GPA mean for student's second year & 2.93 & .92 & & \\
GPA mean for all students & 3.23 & .89 & & \\
\hline
\end{tabular}


Table 4. Two-Sample $t$-Test with Equal Variances

\begin{tabular}{lcccrrrrrl}
\hline \multicolumn{1}{c}{ Group } & & Obs 1 & Obs 2 & Mean 1 & Mean 2 & Dif. & St Err & $\boldsymbol{t}$-value & $\boldsymbol{p}$-value \\
\hline by Gender & IH & 209 & 322 & 78.71 & 77.94 & .77 & .70 & 1.1 & .27 \\
& EI & 209 & 322 & 131.04 & 127.12 & 3.92 & 1.1 & 3.55 & $.001^{* * *}$ \\
by academic levels & IH & 140 & 391 & 77.96 & 78.35 & -.38 & .76 & -.50 & .62 \\
(first and second years) & EI & 140 & 391 & 128.79 & 128.62 & .17 & 1.22 & .15 & .89 \\
by religious activities & IH & 164 & 367 & 78.13 & 78.29 & -.17 & .76 & -.20 & .82 \\
& EI & 164 & 367 & 130.32 & 127.93 & 2.39 & 1.19 & 20 & $.05^{* *}$ \\
\hline
\end{tabular}

Note: $* * * p<.01, * * p<.05, * p<.1$

From the result, the mean for male and female students was significantly different for emotional intelligence. Male students have statistically significantly higher emotional intelligence compared to female students. Those who were involved in religious activities have statistically significantly higher emotional intelligence compared to those who did not involve. Meanwhile, academic levels did not show a significant mean difference for both $\mathrm{IH}$ and EI in the first year and second-year students. To understand the effect of explanatory variables on GPA, we then continued the analysis using regression, as shown in Table 5.

Table 5 shows the significance values of each sub-scale for male and female students in the first and the second academic year. For students in the first year for both males and females, only EI's total score have a significant effect on the GPA. Lack of intellectual over-confidence subscale of male students shows a significant effect on GPA with a negative coefficient.

For students in the second year, the total IH score on male students and the independence of intellect and ego sub-scale have a significant effect on the GPA. In female students, managing own emotions (with positive coefficient value) and independence of intellect and ego (with negative coefficient value) sub-scales have a significant effect on GPA. When adding religious activities variable into the model, the results make very little difference for the significance.

Table 5. Multiple Regression Analysis with GPA as the Dependent Variable $(N=531)$

\begin{tabular}{|c|c|c|c|c|c|}
\hline & \multirow{2}{*}{ Sub-Scale } & \multicolumn{2}{|c|}{ First Year } & \multicolumn{2}{|c|}{ Second Year } \\
\hline & & Male & Female & Male & Female \\
\hline \multirow[t]{4}{*}{$\begin{array}{l}\text { Intellectual } \\
\text { humility (IH) }\end{array}$} & Independence of intellect and ego & .85 & .30 & $\begin{array}{l}.08^{*} \\
(.05)^{\mathrm{a}}\end{array}$ & $\begin{array}{l}-.06^{*} \\
(-.06)^{\mathrm{a}}\end{array}$ \\
\hline & $\begin{array}{l}\text { Openness to Revising One's } \\
\text { Viewpoint }\end{array}$ & .42 & .95 & .77 & .87 \\
\hline & Respect for other's viewpoints & .56 & .18 & .54 & .55 \\
\hline & Lack of intellectual over-confidence & $\begin{array}{l}-.06^{*} \\
(-.06)^{\mathrm{a}}\end{array}$ & .69 & .34 & .65 \\
\hline \multirow{4}{*}{$\begin{array}{l}\text { Emotional } \\
\text { intelligence (EI) }\end{array}$} & Perception of emotion & .22 & .52 & .13 & .89 \\
\hline & Managing own emotions & .58 & .22 & .25 & $\begin{array}{l}.02 * * \\
(.03)^{\mathrm{a}}\end{array}$ \\
\hline & Managing others' emotions & .38 & .46 & .71 & .36 \\
\hline & Utilization of emotions & .89 & .17 & .27 & .43 \\
\hline Total EI & & $.09 *$ & $.02 * *$ & .85 & .96 \\
\hline Total IH & & .38 & .21 & $.05 * *$ & .54 \\
\hline GPA's mean & & 3.16 & 3.31 & 3.12 & 2.77 \\
\hline Respondents & & 142 & 249 & 67 & 73 \\
\hline
\end{tabular}

Note: 1$) * * * p<.01, * * p<.05, * p<.1$

2) superscript a means that there was a change of significant value when we included religious activities into the model 


\section{Discussion}

In this current study, the first hypothesis that we proposed does not meet our expectations. Here, our main expectation was student's level of academic years should have shown significant differences for both intellectual humility and emotional intelligence. It is, however, for emotional intelligence where only gender and engagement in religious activities have statistically significant evidence. For the second hypothesis, while only intellectual humility for male students in the second year has a statistically significant relationship, emotional intelligence for students in the first year both for male and female shows statistically significant relationship with academic achievement. We try to shed some light on these results for understanding them deeper and clearly.

\section{Education, Intellectual humility, and Emotional Intelligence}

As discussed by Ahmed et al. (2019), in the context of Indonesian students, academic achievement is an important variable as well as corresponds with employment, career success, and family honour. Unfortunately, discussions and research on the influence of emotions concerning academic success in the educational field, especially at the university level, are very few and rarely conducted. So far, it has been only conducted for difficult subjects (Maksum, 2013; Purnama, 2016). Our current study seeks to understand it at the university level.

It has long been the attention of practitioners or educators that gender issues have been taken into consideration in psychological and educational research, especially related to achievement motivation. Though the research showed different results about academic achievement, learning motivation, task performance (Ahmed et al., 2019), our result is more consistent with Bitner's finding. He stated that there was an influence of emotional factors on male students related to science selfefficacy, course grades, and mastery experiences (Britner, 2008). Students who have a strong belief that they will succeed in the learning process will be more likely to persevere in the face of difficulty. On the other hand, such emotional states seem to make intellectual humility depend on the situation which explains why male students in each EI sub-scale has not a significant relationship as table 5 shows. Using a connectionist approach, someone who is dealing with facts/data and emotional factors tends to experience emotional distortions when thinking about decisions, how they see themselves, and other beliefs. In the context of education, male students appear to be in a durable emotional weight between how to avoid mistakes or bad grades and how to approach academic success or good grades (Hoyle et al., 2016).

The intriguing result was concerning religious activities. A society in which religion has always been a source of profound emotional experience, the society makes religious principles and practices become a guide for the meaning of action. Religious principles are considered to be the most reliable way to cope with difficulties. First of all, it does not concern emotions themselves, but with the meaning understood as theological questions, which are also psychological (Corrigan, 2009). When this variable is included as an indicative factor in the education process, that variable can provide hints about a person's emotions dealing with social pressure, academic ability, and educational pressures (Levenson, Aldwin, \& Igarashi, 2005). Research pertinent to meaningactions in the world of education showed that emotions have an impact on the student's academic process related to the problem of the formation of students' meaning-existential strategies (Naurzalina, Tolegenova, Karabalina, Almurzayeva, Bakiyeva, \& Sadykova, 2015). In the context of our study, these significant differences showed challenges through which students encounter and how they organize emotions to be better by directing the problem of existential meaning to religious principles or practices as a guide of self-regulation.

On the other side, our prediction that mean difference for both emotional intelligence and intellectual humility at the level of academic years showed no significant difference. This result indicated that each academic level has its challenges which involve both emotions and humility. From the finding, we can state that Barchad's doubt about the difference of emotional influence at different years of academics does not occur. It seems that to find out and demonstrate the existing differences significantly, both emotions and humility at the academic levels might indeed be difficult (Mayer 
et al., 2016).

Regarding students' intellectual humility, we previously hoped there were significantly intellectual humility's differences at academic levels, gender, and religious activities. Emotional aspects that dominate strongly and then suppress cognitive aspects can lead a person not to be opened to new ideas, even new solutions as a way out of their problems. Our finding on IH did not indicate the students' efforts to be better cognitively except for emotional selfconfidence or their wishful thinking. This current finding lacks evidence to confirm that appropriately harnessing the motivational aspects of emotion, therefore, could help one's intellectual engagement with another and fuel critical rational processing and reflection in a way that is less distorted and biased (Church \& Samuelson, 2017).

Despite the non-significance of IH, we believe that it is possible to teach, develop, and improve levels of intellectual humility in university students through a teaching intervention that help them to gain advantageous resources and prepare them for a university-work transition (Baehr, 2016; Monteiro, Ferreira, \& Almeida, 2020). Generally, for the Indonesian context, the paradigm relating to academic score needs to be reconsidered since academic score refers solely to the cognitive aspect, not all categories of personality attributes. Furthermore, the changes in the workplace lead to an emphasis on how well a student can think and learn which means that there are tendencies to be less concerned with what students learned in university.

\section{Correlations between the Sub-Factors of Emotional Intelligence and Intellectual Humility}

The result of our study showed that overall emotional scores of students in the first year have a significant influence on academic achievement scores (GPA) for both male students (sig. $=.09)$ and female students $($ sig. $=.02)$. Although the GPA score that they filled in the questionnaire was an expectation of academic achievement, the result shows optimism for achieving excellent academic performance. This finding supports and confirms that emotions are associated with high optimism (Dembo \& Seli, 2016). Such a relationship becomes one of the motivational advantages in achieving excellent academic performance. The GPA's mean also reported a high value for males (3.16) and females (3.31).

The EI sub-scale for both male and female students, however, did not show a significant influence on GPA. There were most likely other factors referred to as constant variables that influenced emotions and were only significantly shown apart from the EI's total score. At this point, external factors that are not included in the research model confirmed the statement that the non-intellectual features cause constructirrelevant to people's self-estimated abilities such as self-confidence, self-esteem, and wishful thinking. If this is correct, then the significance of the IH sub-scale in male students, namely the lack of intellectual over-confidence, showed such a tendency. Male students in the first year tended to show self-confidence to balance and moderate intense academic pressure. This is consistent with the finding that the transition from high-school to the university makes students need to balance emotions (Chinyere \& Afeez, 2019). However, excessive emotional suppression often results in losing clear direction of the cognition. The more students are confident of their abilities, the more they will try to prove themselves emotionally (Velayutham, Aldridge, \& Fraser, 2012).

In explaining the effect of EI and IH on GPA in second-year students, questions arise relating to students' efforts to obtain excellent academic performance. Such questions arise because the statistical result for students in the second year showed a low score for GPA' mean, especially for female students. Several studies have shown several possible reasons. First, it might be that the view of the role of women in the middle of society, especially after they complete their education (Ratnasari \& Suleeman, 2017). The strong stigma of gender differences expressed as "why should I get an excellent academic achievement if later I will become a housewife' or 'I go to college because to raise my social status and family in the middle of society' are depicted by female students. The result confirmed that someone's feelings serving as embodied information about one's immediate concerns and their situated information value could change the orientation of academic achievement to anxiety over their gender roles (Meece, Glienke, \& Burg, 2006). Thus, female 
students tended to understand that academic achievement is not a priority in their academic success.

Second, the emotional instability of female students when dealing with levels of difficulty compared to male students. The statistical result showed that scores for the EI sub-scale, managing own emotions, in female students have a significant effect on GPA compared to male students. The result was consistent with (Meece et al., 2006) that female students indicate anxiety when they found unexpected results as shown by the GPA mean (2.76 compared to male, 3.11). In this regard, female students tried to stabilize emotions using self-regulatory strategies to make the duration or intensity of those emotions better (Middleton, Buboltz, \& Sopon, 2015).

Meanwhile, unlike previous research, although male and female students have a significant mean difference in one of four IH sub-scales, namely independence of intellect and ego, the coefficient values are different. Positive coefficient values for male students in the second year explain stronger academic self-efficacy than female students (marked by negative coefficients). The different GPA's mean between male and female students reinforces our statement of academic self-efficacy. If so, what we found is contrary to Church and Samuelson's statement that emotions (in male students) may lead them to maintain a default position, closing oneself off to the ideas of the others (Church \& Samuelson, 2017).

The development of interest in $\mathrm{IH}$ relating to EI, in Indonesian higher education, has not shown a significant contribution yet. Theoretically, appropriate treatment on student's $\mathrm{IH}$ and EI help them develop adaptive resources as well as academic resilience during their academic learning. Our empirical evidence, however, shows that developing EI and IH may be equally important yet they are suggested to associate with crystallized but not fluid intelligence, regardless of the fact that they are strongly related to academic achievement (Krumrei-Mancuso et al., 2020; Mishra \& Mohapatra, 2010). Hence, it is a persuasive suggestion for other universities because recent educational process of some universities obviously seeks to accommodate and integrate entrepreneurship into theiracademic process by of course understanding it in a broader scope which is associated with more intellectual curiosity, intellectual openness, and open-minded thinking while at the same time promoting collaborative and cooperative learning as enhancing emotional well-being. In other words, both EI and IH help students remain hopeful in difficult times and develop their employable skills for their future.

\section{Practical Implication}

The currentfindings provide some practical suggestions for educators or practitioners in higher education. First, taking into consideration that employability is one of the main agendas to create a qualified graduate, students might be aware that they need more than a set of scientific and technical programmes. That is to say, although academic process focuses on technical competencies, it is more important to foster student's employability in a more comprehensive way than prepare them to search for a study-matched job. Based on our results, students in the first-year curricula programmes should be equipped with adaptability resources to manage their own attributes in coping with difficulties. GPA is important, but letting it be on students own efforts may issue moral dilemma since they perceive it as a higher priority over other factors which is then seen as a deviantbehavior (Cartwright \& Menezes, 2014; Ratu, Rai, Prasetya, \& Yoga, 2018). Thus, it follows that lecturers should teach their students as an emotionally intelligent practice which then fosters student's intellectual humility to continuously plan, adapt, adjust, and evaluate their set of competencies. Second, it also may be beneficial that students need to actively engage in a non-academic activity which helps them to firstly develop their insights emotionally. Especially for female students, the activities can help them to discern their role and future aside from an academic process.

\section{Recommendation and Limitation}

Following practical implications, we have two points to recommend. First, in balancing the cognitive aspect of academic process, we suggest a mentor programme on both career and academic dimensions in order to make them enjoy and comfortable during their educational process. Second, social or religious-based activities need to have a place, not only as part of the academic process, in accommodating and 
facilitating student's exploration and inspiration with which they feel and can act on it, so they realize that an agent of change for their future occupation is at their hands.

Although these findings are encouraging, some limitations should be noted. First, this study is restricted to Indonesian college students. Because the data was collected at one time, the use of other methods needs to be considered, especially for understanding possible pre- and post-interventions of $\mathrm{EI}$ and $\mathrm{IH}$, specifically in experimental research. This consideration is necessary as an effort to engender greater confidence in the findings. In our context, an understanding of emotions tends to be related to one's trait, not problem-solving abilities. The second limitation is an understanding of the conceptual relationships between emotional intelligence and intellectual humility sub-scale. Our study does not focus on the high, medium, low categories for each construct, either EI, IH, and GPA. Future research needs to consider this ordinal category in order to understand it as one effort of contributing to academic success. The findings of this study are based solely on the analysis and interpretation of data collected using the questionnaire. The final limitation is the influence of religious factors on both EI and IH in efforts to achieve excellent academic performance. For future research, the use of other methods is recommended for understanding religious factors concerning EI and $\mathrm{IH}$.

\section{CONCLUSION}

A significant contribution of this study is the identification of the IH and EI sub-scale that influences students' academic achievement. The results revealed that the total EI affected the GPA of male and female students in the first year. While in the second year, only the total IH was influential for male students. These findings present possible opportunities for educators to plan, and put into practice, effective instructional intervention strategies aimed at increasing students' EI and IH. The pedagogical intervention model would be to target the students and develop effective strategies for achieving academic success. Without reason, emotion lacks clear direction to achieve high academic achievement. However, without emotion, the ability to reason is impaired.

A robust understanding of $\mathrm{IH}$ as an indication to understand students' abilities during the educational process is impossible without serious attention to emotion, including the religious dimension as a source of motivation and adaptive function. If the education process is believed to be a platform for the formation of character and a work-ready landscape, EI should be integrated as part of an academic program. Students need to feel their emotions to enhance a positive outlook on the situation they are experiencing. When emotions are kept in check, students can know their minds, motives, reasons, and act reasonably.

\section{AKNOWLEDGMENTS}

We thank DRPM Sepuluh Nopember Institute of Technology for funding our research. The views conveyed in this publication do not necessarily represent the views of the supporting institution.

\section{REFERENCES}

Ahmed, Z., Asim, M., \& Pellitteri, J. (2019). Emotional intelligence predicts academic achievement in Pakistani management students. The International Journal of Management Education, 17(2), 286-293. https://doi.org/https://doi.org/10.1016/j. ijme.2019.04.003.

Baba, M. M., Makhdoomi, U. M., \& Siddiqi, M. A. (2019). Emotional intelligence and transformational leadership among academic leaders in institutions of higher learning. Global Business Review, 1-27. https://doi. org/10.1177/0972150918822421.

Baehr, J. (2016). Is intellectual character growth a realistic educational aim? Journal of Moral Education, 45(2), 117-131. https:// doi.org/10.1080/03057240.2016.117467 $\underline{6}$.

Baehr, J. (2017). Encyclopedia of educational philosophy and theory. Singapore: Springer. https://doi.org/10.1007/978981-287-588-4.

Barchard, K. A. (2003). Does emotional intelligence assist in the prediction of academic success? Educational and Psychological Measurement, 
63(5), $\quad$ 840-858. $\quad$ https://doi. org/10.1177/0013164403251333.

Palmer, B. R., Stough, C., Harmer, R., \& Gignac, G. (2009). The genos emotional intelligence inventory: A measure designed specifically for workplace applications. In J. D. A. Parker, D. H. Saklofske, \& C. Stough (Eds.). Assessing emotional intelligence: Theory, research, and applications. Boston, MA: Springer, pp. 103-117. https://doi.org/10.1007/9780-387-88370-0.

Britner, S. L. (2008). Motivation in high school science students: A comparison of gender differences in life, physical, and earth science classes. Journal of Research in Science Teaching, 45(8), 955-970. https:// doi.org/10.1002/tea.20249.

Cartwright, E., \& Menezes, M. L. C. (2014). Cheating to win: Dishonesty and the intensity of competition. Economics Letters, 122(1), 55-58. https://doi. org/10.1016/j.econlet.2013.10.016.

Chinyere, O. T., \& Afeez, Y. S. (2019). Influence of emotional intelligence ability level of electrical/electronic technology university students on academic motivation and attitude to study. International Journal of Electrical Engineering Education, $0(0), \quad 1-41$. https://doi. org/10.1177/0020720919840984.

Church, I. M., \& Samuelson, P. L. (2017). Intellectual humility: An introduction to the philosophy and science. New York, NY: Bloomsbury Academic.

Corrigan, J. (2009). Introduction: The study of religion and emotion (Vol. 1). In J. Corrigan (Ed.). The Oxford handbook of religion and emotion. Oxford: Oxford University Press, pp. 3-13. https://doi.org/10.1093/ oxfordhb/9780195170214.003.0001.

Dembo, M. H., \& Seli, H. (2016). Motivation and learning strategies for college success. Motivation and learning strategies for college success. New York, NY: Routledge. https://doi.org/10.4324/9781315724775.
Dormandy, K. (2018). Does epistemic humility threaten religious beliefs? Journal of Psychology and Theology, 46(4), 292-304. https://doi. org $/ 10.1177 / 0091647118807186$.

Fetterman, A. K., Curtis, S., Carre, J., \& Sassenberg, K. (2019). On the willingness to admit wrongness: Validation of a new measure and an exploration of its correlates. Personality and Individual Differences, 138, 193-202. https://doi. org/10.1016/J.PAID.2018.10.002.

Hopkin, C. R., Hoyle, R. H., \& Toner, K. (2018). Intellectual humility and reactions to opinions about religious beliefs. Journal of Psychology and Theology, 42(1), 50-61. https://doi. org/10.1177/009164711404200106.

Hoyle, R. H., Davisson, E. K., Diebels, K. J., \& Leary, M. R. (2016). Holding specific views with humility: Conceptualization and measurement of specific intellectual humility. Personality and Individual Differences, 97, 165-172. https://doi. org/10.1016/j.paid.2016.03.043.

Jan, S. U., Anwar, M. A., \& Warraich, N. F. (2018). The relationship between emotional intelligence, library anxiety, and academic achievement among the university students. Journal of Librarianship and Information Science, 52(1), 1-12. https:// doi.org/10.1177/0961000618790629.

Jenaabadi, H. (2014). Studying the relation between emotional intelligence and self esteem with academic achievement. Procedia-Social and Behavioral Sciences, 114, 203-206. https://doi.org/10.1016/j. sbspro.2013.12.685.

Kidd, I. J. (2011). Pierre Duhem's epistemic aims and the intellectual virtue of humility: A reply to Ivanova. Studies in History and Philosophy of Science Part A, 42(1), 185-189. https://doi.org/10.1016/j. shpsa.2010.11.007.

Krumrei-Mancuso, E. J. (2017). Intellectual humility and prosocial values: Direct and mediated effects. The Journal of Positive 
Psychology, 12(1), 13-28. https://doi.org/ 10.1080/17439760.2016.1167938.

Krumrei-Mancuso, E. J., Haggard, M. C., LaBouff, J. P., \& Rowatt, W. C. (2020). Links between intellectual humility and acquiring knowledge. The Journal of Positive Psychology, 15(2), 155-170. https://doi.org/10.1080/17439760.2019.1 579359.

Krumrei-Mancuso, E. J., \& Rouse, S. V. (2016). The development and validation of the comprehensive intellectual humility scale. Journal of Personality Assessment, 98(2), 209-221. https://doi.org/10.1080/002238 91.2015.1068174.

Leary, M. R., Diebels, K. J., Davisson, E. K., Jongman-Sereno, K. P., Isherwood, J. C., Raimi, K. T., ... Hoyle, R. H. (2017). Cognitive and interpersonal features of intellectual humility. Personality and Social Psychology Bulletin, 43(6), 793-813. https://doi. org/10.1177/0146167217697695.

Levenson, M. R., Aldwin, C. M., \& Igarashi, H. (2005). Religious development from adolescence to middle adulthood. In R. F. Paloutzian \& C. L. Park (Eds.). Handbook of the psychology of religion and spirituality $\left(1^{\text {st }}\right.$ ed). New York, NY: Guilford Press, pp. 144-161.

Majeski, R. A., Stover, M., Valais, T., \& Ronch, J. (2017). Fostering emotional intelligence in online higher education courses. Adult Learning, 28(4), 135-143. https://doi. org/10.1177/1045159517726873.

Maksum, K. (2013). Hubungan kecerdasan emosional dan motivasi dengan tingkat prestasi belajar siswa kelas $\mathrm{V}$ pada mata pelajaran bahasa indonesia. [The relationship between emotional intelligence and motivation with the level of student achievement in grade $\mathrm{V}$ in Indonesian subjects]. Muaddib: Studi Kependidikan Dan Keislaman, 3(1), 3662. https://doi.org/10.24269/muaddib. v3i1.63.

Mardiana, C. F. (2017, 29 August). 63\% Orang indonesia bekerja tak sesuai jurusan. [63\% of Indonesians work not according to their majors]. Detik Finance. https:// finance.detik.com/berita-ekonomi-bisnis/ d-3620313/63-orang-indonesia-bekerjatak-sesuai-jurusan.

Mayer, J. D., Caruso, D. R., \& Salovey, P. (2016). The ability model of emotional intelligence: Principles and updates. Emotion Review, 8(4), 290-300. https:// doi.org/10.1177/1754073916639667.

Mayer, J. D., Salovey, P., \& Caruso, D. R. (2008). Emotional intelligence: New ability or eclectic traits? American Psychologist, 63(6), 503-517. https://doi. org/10.1037/0003-066X.63.6.503.

Meece, J. L., Glienke, B. B., \& Burg, S. (2006). Gender and motivation. Journal of School Psychology, 44(5), 351-373. https://doi. org/10.1016/j.jsp.2006.04.004.

Middleton, J., Buboltz, W., \& Sopon, B. (2015). The relationship between psychological reactance and emotional intelligence. Social Science Journal, 52(4), 542-549. https://doi.org/10.1016/j. soscij.2015.08.002.

Mishra, P. S., \& Mohapatra, A. K. Das. (2010). Relevance of emotional intelligence for effective job performance: An empirical study. Vikalpa, 35(1), 53-62. https://doi. org/10.1177/0256090920100104.

Monteiro, S., Ferreira, J. A., \& Almeida, L. S. (2020). Self-perceived competency and self-perceived employability in higher education: the mediating role of career adaptability. Journal of Further and Higher Education, 44(3), 408-422. https://doi.org 110.1080/0309877X.2018.1542669.

Naurzalina, D., Tolegenova, A., Karabalina, A., Almurzayeva, B., Bakiyeva, S., \& Sadykova, N. (2015). Impact of emotional intelligence on formation of meaningexistential strategy among students. Procedia - Social and Behavioral Sciences, 171, 390-395. https://doi. org/10.1016/j.sbspro.2015.01.137. 
Ngah, R., Wahyukaton, W., Salleh, Z., \& Sarmidy, R. (2016). Comparative study of emotional intelligence and entrepreneurial orientation between malaysian and indonesian university students. Procedia Economics and Finance, 37(16), 100$107 . \quad$ https://doi.org/10.1016/s22125671(16)30099-5.

Preston, J. L., \& Shin, F. (2017). Spiritual experiences evoke awe through the small self in both religious and non-religious individuals. Journal of Experimental Social Psychology, 70, 212-221. https:// doi.org/10.1016/j.jesp.2016.11.006.

Purnama, I. M. (2016). Pengaruh kecerdasan emosional dan minat belajar terhadap prestasi belajar matematika di SMAN Jakarta Selatan. [The influence of emotional intelligence and interest in learning on mathematics learning achievement at SMAN Jakarta Selatan]. Formatif: Jurnal Ilmiah Pendidikan MIPA, 6(3), 26-41. https://doi.org/10.30998/ formatif.v6i3.995.

Ratnasari, S., \& Suleeman, J. (2017). Perbedaan regulasi emosi perempuan dan lakilaki di perguruan tinggi. [Differences in Emotional Regulation of Women and Men in Higher Education]. Jurnal Psikologi Sosial, 15(1), 35-46. https://doi. org/10.7454/jps.2017.4.

Ratu, A., Rai, N. G., Prasetya, N., \& Yoga, D. S. (2018). Is self-efficacy related to students' moral reasoning?: a research on students' absentee behavior. In Proceedings of the 3rd International Conference on Psychology in Health, Educational, Social, and Organizational Settings (Vol 1). Scitepress, pp. 397-405. https://doi. org/10.5220/0008590003970405.

Schei, E., Fuks, A., \& Boudreau, J. D. (2019). Reflection in medical education: Intellectual humility, discovery, and know-how. Medicine, Health Care and Philosophy, 22(2), 167-178. https://doi. org/10.1007/s11019-018-9878-2.
Schutte, N. S., Malouff, J. M., Hall, L. E., Haggerty, D. J., Cooper, J. T., Golden, C. J., \& Dornheim, L. (1998). Development and validation of a measure of emotional intelligence. Personality and Individual Differences, 25(2), 167-177. https://doi. org/10.1016/S0191-8869(98)00001-4.

Van Yperen, N. W., Hamstra, M. R. W., \& Van Der Klauw, M. (2011). To win, or not to lose, at any cost: The impact of achievement goals on cheating. British Journal of Management, 22(S1), S5-S15. https://doi. org/10.1111/j.1467-8551.2010.00702.x.

Velayutham, S., Aldridge, J. M., \& Fraser, B. (2012). Gender differences in student motivation and self-regulation in science learning: A multi-group structural equation modeling analysis, 10, 1347-1368. https:// doi.org/10.1007/s10763-012-9339-y.

Watson, L. (2018). Educating for good questioning: A tool for intellectual virtues education. Acta Analytica, 33(3), 353370. https://doi.org/10.1007/s12136-0180350-y.

Wrench, J. S., Punyanunt-Carter, N. M., \& Garcia, A. J. (2020). Understanding college students' perceptions regarding mindfulness: The impact on intellectual humility, faith development, religious communication apprehension, and religious communication. Journal of Religion and Health, 59(4), 1794-1809. https://doi.org/10.1007/s10943-01900861-3.

Yeoh, P.-L. (2019). A critical assessment of skills and knowledge for entry-level marketing jobs: A delphi study: An abstract. In P. Rossi \& N. Krey (Eds.). Finding new ways to engage and satisfy global customers: Proceedings of the 2018 Academy of Marketing Science (AMS) World Marketing Congress (WMC). Cham: Springer, pp. 359-359. https://doi. org/10.1007/978-3-030-02568-7 93. 


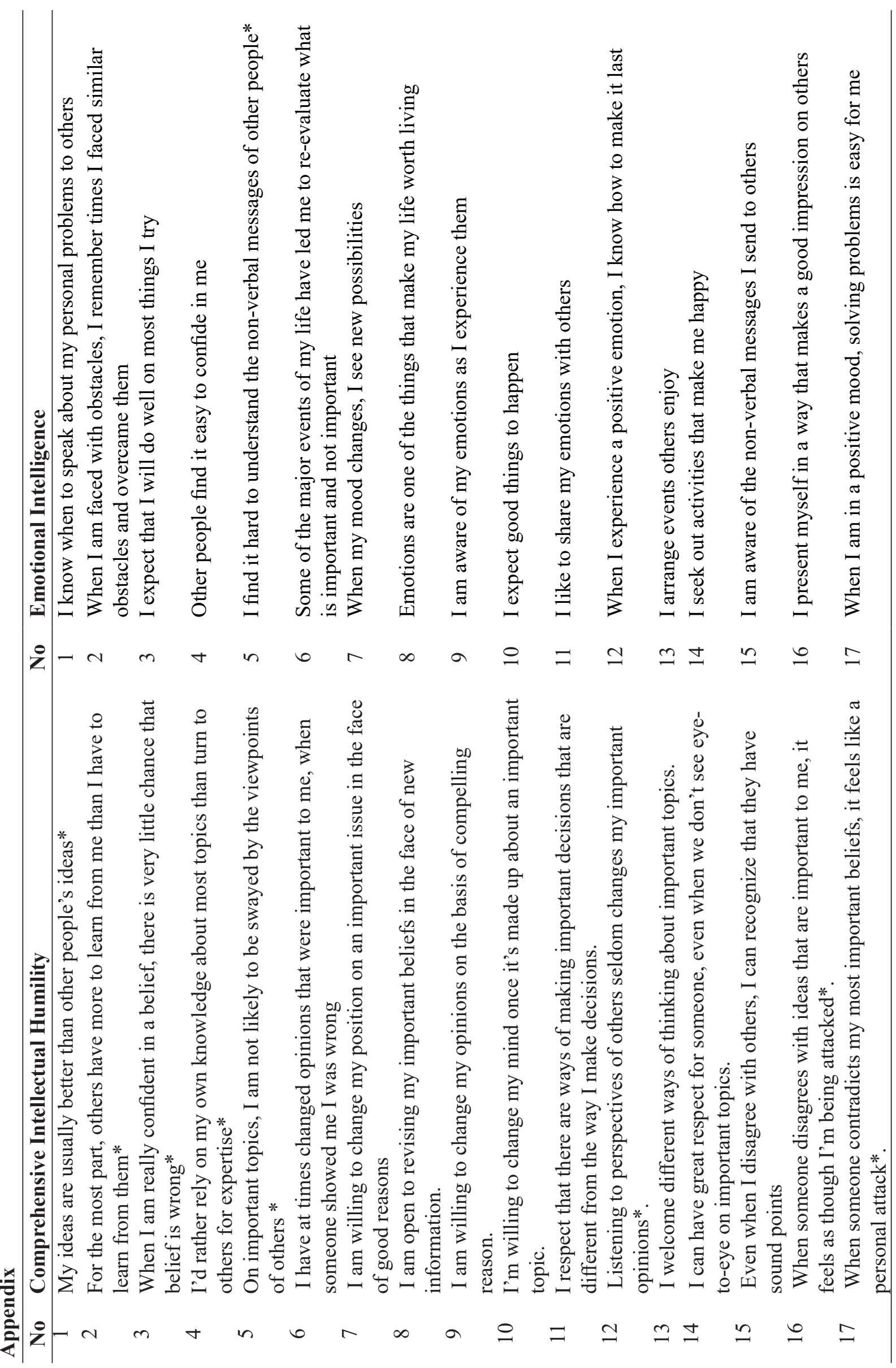




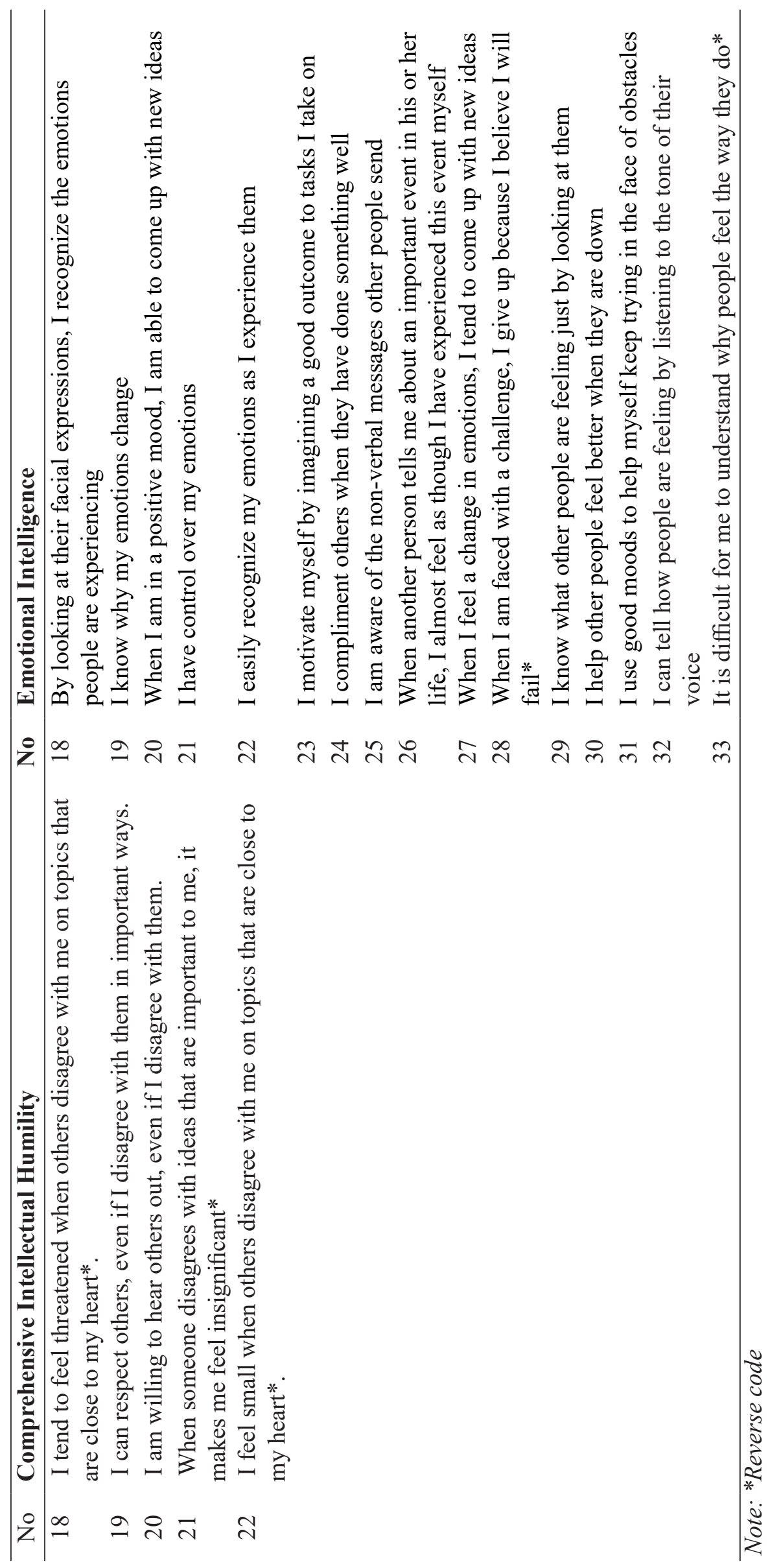

